\title{
Family, War, and Democracy: The Fortunes of Liberalism and Conservatism in Post-1960s America.
}

Brian Mueller, University of Wisconsin-Milwankee

\section{Robert O. Self, All in the Family: The Realignment of American Democracy Since the 1960s (New York: Hill and Wang, 2012).}

\section{Roger Peace, $A$ Call to Conscience: The Anti-Contra War Campaign (Amherst: University of Massachusetts Press, 2012).}

Over the last two decades several influential studies have appeared that document the rise of conservatism. ${ }^{1}$ A common theme in many of these books is the diverse constituencies that aided in the conservative ascendancy did not receive equal attention from conservative politicians. This argument is predominant when historians look at the influence of evangelical Christians and supporters of a free-market economy on conservatism. Republicans spoke out in favor of outlawing abortion and about the need to protect the sanctity of marriage and the family-issues of utmost importance to evangelical Christians-but legislative accomplishments rarely matched this rhetoric. Instead, politicians like Ronald Reagan focused on tax cuts and deregulation. In All in the Family, Robert O. Self offers an alternative view of the decline of liberalism and the rise of conservatism by looking at how matters pertaining to the American family since the 1960s allowed conservative politicians to rise to power.

Self organizes his book under two similar, yet distinct, conceptions of the nuclear family from 1964 until 2004. Using 'the family' is, of course, not something new when it comes to studying the rise of conservatism. ${ }^{2}$ However, in contrast to these other studies, Self's exhaustive account delves into how the social movements of the 1960s and 1970s weakened the liberal conception of family, thereby making room for the new view of the family put forth by conservatives. Whereas the social programs instituted by the New Frontier and the Great Society sought to remove some of the roadblocks to forming a nuclear family and acquiring all of its trappings, conservatives in the 1970s and beyond wanted to protect the nuclear family from immoral and totalitarian forces. Self labels the former efforts "breadwinner liberalism" and the latter attempts "breadwinner conservatism." 3 While examining the conflicting views of the nuclear family offered by liberals and conservatives, Self also uses this framework to show that the split between so-called "values" voters and advocates of the free-market did not actually exist. Self questions the veracity of separating the goals and aspirations of participants of the culture war-which involved issues of gender, sexuality, and family - from the economic programs favored by 
free-market conservatives. Self contends the distinction between negative rights_-rights that exist because the government chooses not to restrict the actions of a particular group or individual — and positive rights - where the government develops laws to prevent injustices from occurring-paralleled the debates over greater or lesser economic intervention by the government. Broken into four parts, Self devotes more than half of the book to documenting the continuous weakening of breadwinner liberalism as a result of protests by gay rights activists, feminists, and civil rights activists. Demands made by women, homosexuals, and minorities for expanded "rights" resulted in greater freedom for these groups. At the same time, however, their efforts brought into question the role of the breadwinner in the nuclear family. Breadwinner liberalism, as Self shows, came under attack from all sides during the 1960s. Liberal social programs, whether the Social Security and Wagner Act of the 1930s or the War on Poverty in the 1960s, for the most part, ignored the contributions of women in the workplace, choosing instead to view women as tending to the home. Such a gendered perspective created many difficulties for women and came under increasing scrutiny from feminists. Likewise, liberal programs that sought to elevate the standing of African American males in order to strengthen the black family angered many working-class whites. Conservatives, furthermore, attacked breadwinner liberalism for not allowing the male to succeed by his own efforts. As various groups questioned liberalism's emphasis on the white, male breadwinner, liberalism itself experienced a decline. The story of liberalism's decline is well known, but by situating this decline in the larger story of the family, Self's framework shows a direct correlation between how the demand for greater "rights" led to a conservative ascendancy.

When breadwinner liberalism came under attack, many of its detractors, either directly or indirectly, questioned the male-dominated structure of the nuclear family. Males had been able to prove their manhood through their role as the sole money-earner in the nuclear family. In addition to their economic standing, males also had used heterosexuality as a means to demonstrate their manhood. Gay rights activists, known primarily as homophiles prior to the late 1960 s, had been demanding greater rights as early as 1950, when they formed the Mattachine Society. These early homophiles demanded negative rightsespecially the right to do as they chose in private settings. Later activists, emboldened by the police actions at Stonewall Inn in New York City in 1969, sought sexual liberties beyond the private confines of their homes. This represented, according to Self, "an entirely new . . unimagined sexual citizenship" that threatened manliness and the nuclear family. ${ }^{4}$ Self argues the "sexual citizenship" demanded by gay rights activists, as well as other forms of citizenship that the various rights movements fought for, played a key role in antagonizing Americans who, in turn, increasingly looked to conservatism as being better equipped to deal with their complaints. 
Alternative conceptions of citizenship, in Self's telling of the rise of breadwinner conservatism, did the most to bring about the conservative successes of the 1970s and 1980s. In the past, America's social contract provided benefits — including pensions, healthcare, and employment insurance-only to working Americans, thereby excluding many women. When the government had previously offered proposals for government-sponsored childcare, it did so with the intention of moving women off of welfare and into steady employment. In 1971, however, Walter Mondale (D-MN) and representative John Brademas (DIN), put forth the Comprehensive Child Development Act. Describing it as "quietly revolutionary," Self argues that it "redefined the social contract itself," by allowing for "social citizenship" rather than "economic citizenship." If passed, the bill would have greatly enlarged the social contract to include all women, not only those women with steady work. ${ }^{6}$ In the end, President Nixon vetoed the bill over concerns that government-run child care centers would give government officials too much influence in matters that were out of the purview of the government. Families, conservatives argued, needed to care for their children, not some bureaucrat thousands of miles away.

Expansion of the parameters of citizenship encountered tremendous opposition from conservative activists not only because the citizenship demanded by activists on the left threatened the family, but also because calls for an enlarged citizenship brought with it the need for "positive" rights. Gay men and lesbian women had secured the right to privacy in their homes; legal restrictions on women's employment had become less common; and women obtained greater sexual freedom because the government no longer restricted birth control. These, however, represented "negative" rights since the expansion of freedom came from the removal of restrictions on activities rather than through supplementary laws meant to protect these groups from certain abuses. The government did not have to go through the much more difficult task of providing additional benefits or protections that conservative Americans viewed as unfair. Once these groups gained greater freedoms, it became clear that their newly acquired citizenship extended only so far. Women, as one example, could not achieve "economic citizenship." The Humphrey-Hawkins full-employment bill, for instance, ignored welfare dependents and workers stuck in low-paying part-time jobs. Since mostly women filled these types of jobs, the HumphreyHawkins bill, the bill's critics argued, ignored the economic plight of women. Coming as it did at the time of one of the worst economic downturns since the Great Depression, the full-employment legislation already faced an uphill battle as the government looked for ways to break free from its social contract with American citizens. Women's groups, realizing the difficulties associated with obtaining positive rights, put their support behind the bill and suggested only minimal amendments to the legislation. Positive rights, as Self demonstrates, entered the fray just as government officials turned to neoliberalism as a means of solving the nation's ills. 
The various social movements that came together in the 1960s and 1970s increasingly voiced their claims for greater rights based on a common identity — whether gay, lesbian, woman, black, or Latino. Such "identity politics," as these movements are usually described, have received much criticism from all sides in debates over post-1960s America. Self does not specifically discuss "identity politics," though he does offer one piece of criticism. The problem with using identities to make American citizenship more expansive, according to Self, was that forming groups based on identity to diversify the idea of citizenship actually led to additional limits on citizenship. Within these identity groups existed a variety of sub-identities that took control of the group's efforts to diversify citizenship. Thus male homophiles had to combat heterosexuality, but lesbians had to do the same with male homophiles, and ethnic groups involved in the homophile and feminist struggles had to battle racism on top of the injustices faced by women and gays.

Out of all the social movements that arose in the period covered in Self's book, perhaps no other experienced as much division as the women's movement. As Self has shown, Second Wave feminists held varied views of "motherhood." Working-class women wanted to make it possible for women to both work outside of the home and care for their family, so they demanded that the government provide childcare. Another view of motherhood, this one favored by Betty Friedan and Gloria Steinem, called for childcare, but also explained the importance of males needing to take on more responsibilities at home. Some feminists even questioned why women would want a career that often times meant they would have to do demeaning work. The National Welfare Rights Organization, for instance, viewed motherhood as much more valuable than low-paid employment. A more radical view of motherhood provided by Kate Millett and Shulamith Firestone, among others, posited that nuclear families fostered patriarchal relationships. An additional fragmentation of the women's movement occurred when lesbian feminists began to distinguish their problems from those of heterosexual women. These divisions became clear when lesbians fought for the right to raise their own children following a divorce from their husband. Citizenship for lesbian mothers required, Self shows, not only the negative right of privacy in the bedroom, but also the positive right of lesbians to maintain custody of their children. In order to illustrate their ability to nurture their children, many lesbians, going against earlier efforts by feminists, presented their arguments in a way that situated lesbians within the "traditional" framework of motherhood where the mother acted as caregiver and housekeeper.

As its constituency demanded an expanded conception of citizenship, liberals inside and outside of the Democratic Party attempted to chart the best course to take to achieve such a goal. According to Self, George McGovern, at the Democratic Party convention in 1972, strove to find a way to carry out the activist demands of the 1960s in a manner that preserved the coalition created 
during the New Deal. Thus, on abortion—an issue which McGovern had only mildly supported throughout the campaign— the candidate not only allowed Frances Farenthold, a Texas state legislator, to give a speech decrying government interference in women's lives, but also Missouri delegate Eugene Walsh, who compared abortion to murder. Likewise, McGovern made the politically motivated decision to refuse to include any mention of gay rights in his platform and left discussion of the gay rights minority plank until after 4:00 a.m. After the gay rights activists finally spoke, Ohio delegate Kathleen Wilch took the stage and linked homosexuality to sexual abuse. The next day Wilch accused a lawyer from the staff of the platform committee of writing the speech, thereby tying McGovern to the debacle. McGovern's disastrous 1972 nominating convention, Self claims, signaled "the nation's circle of equal citizenship had run into the reality of political efficacy."7 Efforts by activists to make liberals and the Democratic Party broaden their conception of the family and breadwinner liberalism had, as the 1972 convention made clear, failed miserably.

Despite the middle-of-the-road approach taken by McGovern at the 1972 Democratic national convention, continued activism by women eventually led to the revision of the liberal breadwinner ideal. According to Self, the White House Conference on Families report, based on conferences held in Los Angeles, Minneapolis, and Baltimore in 1980, and the International Women's Year National Plan of Action, which was based on discussions held at the IFW Conference in Houston in 1977, "embodied a new liberal vision" of citizenship and family in America. ${ }^{8}$ Though still leaning towards the family with a heterosexual male as the sole breadwinner, the report put a greater emphasis on inclusivity, especially as it related to race, gender, and sexual preference. Self's assertion that the two reports represented an alternative liberal construct of citizenship and family illustrates the continued existence of liberalism despite the conservative revival of the 1970s. Nonetheless, while the liberal conception of family-labeled the "adaptive family" by Self to signify those families that did not follow the usual form of a nuclear family with the male as head of the household-seemed to be more widespread, the conservatives "archetypal family" won the "rhetorical war" that mattered so much in politics. ?

A major reason for the conservative resurgence of the 1980s, Self argues, was the cooperation between "family values" conservatives and fiscal conservatives. Breadwinner conservatism, according to Self, allowed Phyllis Schlafly's "contented housewives" and Nixon's "hard hats" to enter into "political matrimony." 10 Anti-Equal Rights Amendment forces claimed that the market had made it difficult for women to find jobs and, therefore, women should celebrate and do everything possible to preserve their priceless roles as mothers and homemakers. The "wife," these activists claimed, needed to appreciate the difficult work her husband did in order to maintain his role as breadwinner while enduring constant attacks by the government, non-whites, and hippies. 
Contrary to popular understanding the differences between the "values" of conservatives and fiscal conservatives did not prevent the two sides from working together. To illustrate the common goals between the two groups of conservatives, Self discusses the "Unity 81 " campaign conducted by conservatives. During "Unity 81," the name given to the inaugural Grassroots Pro-Life Conference, Howard Phillips detailed his plans to "defund the left" by stopping government funding of programs associated with abortion and families. Title X of the 1970 Public Health Services Act, for instance, received much criticism because it provided Planned Parenthood Federation of America with thirty to forty million dollars per year. While Planned Parenthood performed various services, it's most controversial activities included abortions and abortion counseling for teenagers. Federal monies continued to go to Planned Parenthood, but conservatives succeeded in forcing the organization to separate its abortion facilities from its family planning programs. Self provides another example of cooperation between "values" voters and voters concerned primarily with fiscal issues by discussing Reagan's Working Group on the Family. This group, whose participants included Clarence Thomas, William Kristol, and Jo Ann Gasper, who lost her job as deputy secretary of Health and Human Services because of her role in keeping federal funding from going to Planned Parenthood, wrote The Family: Preserving America's Future. The report, published in 1986, called for tax credits for families with children and an end to federal programs that in any way supported homosexuality and teenage sex.

Self recognizes that despite the unifying principles of "family values" and fiscal conservative activists, the former could not celebrate any crowning achievements during Reagan's presidency. Still, Self argues that "family values" and evangelical conservatives succeeded in making "American citizenship" less about "rights" and more about "government provision," or what the government would have to "provide" for these rights to be secured. ${ }^{11}$ Additionally, these conservatives made morality the sole issue, thereby making the left's views on citizenship, family, and government aid seem far more threatening than they had previously been. Though evangelical voters could not celebrate many legislative or legal victories during Reagan's presidency, a less visible but far more fundamental change occurred. Family values, Self contends, made it easier for neoliberal policies to take hold since "family values could flourish only with a weak government that absented itself from both the market and the 'private' domain of family morality."12

The fact remains, however, that Reagan's policies did not offer much of anything to evangelical and family values voters. Neither did Republicans in the first half of the 1990s when, for instance, Newt Gingrich's Contract with America seemed devoid of religious issues. While the "rhetoric of cultural warfare" remained a part of the Republican Party, politicians never forcefully backed 
the actual policies. ${ }^{13}$ It is unclear whether Self would agree with the historian David T. Courtwright's assertion that "the moral revolution of the 1960 s became so entrenched that it defied the most politically successful enemies" due in part to the economic policies of Reagan. ${ }^{14}$

Looking at American society from 1964 until 2004 within the framework of the nuclear family, particularly how rising demands for greater "rights" put in peril the breadwinner ideal of the nuclear family, is ambitious, but Self pulls it off brilliantly. The most significant contribution Self has made is to the literature on liberalism. More questionable, however, is Self's discussion of what role the culture war played in America in relation to morality. Self makes an extremely convincing case when writing about the impact of family values on liberalism and those groups who sought to expand the liberal conception of the nuclear family. His argument, though, does not take into account what successes, if any, family values conservatives had in actually transforming American society. Family values conservatives made possible the neoliberal economic policies of the 1980s, but, beyond politics, can these conservatives claim a victory when it comes to the structure of families in America? It seems that now, more than ever before, the nuclear family, if that term is even useful any longer, is much more elastic.

In addition to "breadwinning" and "heterosexuality," "soldiering," according to Self, represented a "stable triumvirate" of "American manhood."15 During the Vietnam War, draft resisters, military deserters, drug-addicted soldiers, antiwar activists, and soldiers accused of horrific atrocities brought into question the previously assumed relationship between being a soldier and manhood. Running against Jimmy Carter in the 1980 presidential election, Ronald Reagan, supported by his neoconservative advisors, portrayed the president as weak in the aftermath of the Soviet Union's invasion of Afghanistan and the continuing hostage situation in Iran. During the 1980 campaign, Reagan promised to roll-back communism wherever it sought to spread its ideology, especially in Latin America. The previous July, the Sandinista National Liberation Front, after 18 years of battling Somoza's forces, succeeded in forcing Anastasio Somoza-whose dictatorial actions as president of Nicaragua went unnoticed by American officials-out of power.

Once in office, Reagan signed National Security Decision Directive 17 on November 11, 1981, which provided $\$ 19$ million for the Central Intelligence Agency to create the Contras, an anti-Sandinista force in Nicaragua. Unable to prod Congress into funding the Contras, the Reagan administration turned to other sources for financial support to aid the anti-Sandinista forces. Lieutenant Colonel Oliver North led the administration's efforts to seek financial backing from foreign nations and wealthy Americans. Beginning in April 1986, North, despite securing over thirty million dollars from Saudi Arabia and $\$ 10$ to $\$ 20$ 
million from private U.S. citizens like Joseph Coors and singer Pat Boone, proposed a plan whereby weapons would be sold to Iran with the profits from these sales going to fund the Contras. The Reagan administration's methods came to light in late 1986, which led the Senate to hold investigative hearings the following year. ${ }^{16}$ Though dropped in the early 1990s as a result of the immunity given to him during his congressional testimony, Congress charged North with twelve felony accounts. Comparisons between North and Calley immediately began swirling, but, according to Self, North, even more than the controversial Calley, "fully embodied a forthright military manhood."17 Reagan once again popularized the image of America as a freedom-loving nation that sought to extend its democratic institutions to the rest of the world.

Reagan's aggressive foreign policy maneuvers undoubtedly restored the linkage between the military and manhood, but not without reigniting widespread opposition among certain segments of the American populace. Historians view Ronald Reagan's election as the culmination of the conservative ascendency and evidence of the domination of conservative ideals. While this view still prevails, several historians have explored those events of the 1980s that do not fit into the conservative paradigm, particularly in relation to Reagan's Latin American policies, AIDS, and apartheid. ${ }^{18}$ Smaller than the antiwar protests against the Vietnam War, opponents of Reagan's Central America policies, nonetheless, organized several impressive protests and demonstrations in the 1980s. In A Call to Conscience, Roger Peace has provided an informative account of the campaign against Reagan's Nicaraguan policy by looking at the activities of various organizations in the United States. Though Peace took part in the protests against Reagan, he takes a scholarly approach to the material that he is writing on.

Peace begins his account by offering a brief history of previous American interventions in the region that date back to the early twentieth century. In doing this, Peace seeks to connect the work of earlier anti-interventionists to the activists in the 1980s that he writes about. When Calvin Coolidge sent U.S. Marines to Nicaragua without the consent of Congress in late 1926, the Fellowship of Reconciliation and the American Friends Service Committee helped organize a trip led by peace activist John Nevin Sayre and other Americans to Nicaragua to meet with the general of the Liberal faction there, Augusto César Sandino. Though these Americans failed to secure a meeting with Sandino, Sayre left Santino's wife a letter expressing his support for Nicaragua and his disdain for U.S. imperialism. Anti-interventionists opposed the U.S. intervention because Congress had not authorized the action; the evidence used to show that Mexico had supplied weapons to Sandino's troops was faulty; and non-military means had not been employed first. Anti-Contra protestors, Peace argues, later used these same arguments in the 1980s. 
After concluding his discussion of American-Nicaraguan relations through the middle 1980s, Peace provides a general overview of the arguments employed by activists against Reagan's policies. Peace discerns three general arguments used by activists during the 1980s. Many of these activists opposed Reagan's policies by working to shed light on the administration's unlawful actions. The Reagan administration ignored both Boland amendments and their restrictions on sending funds to Nicaraguan anti-Sandinista forces and Executive Order 12333, which made it illegal for the U.S. to take part in any foreign assassinations. Peace argues such arguments were questionable since anti-Contra activists themselves often found it necessary to break the law through civil disobedience. Efforts to portray the Nicaraguan war as another Vietnam fared no better. Widespread public opposition to Reagan's Central American policies never materialized because U.S. troops had not, nor would they ever be, called into action to invade Nicaragua. Also, the success of the Grenada invasion in October 1983 made Americans more receptive towards military interventions. The most articulate and successful argument voiced by anti-Contra activists, according to Peace, involved a demand for negotiations, which had the benefit of large-scale support from Europeans and Latin Americans.

One of the greatest strengths of Peace's book is that he analyzes the activities of a variety of organizations that up until this point have remained invisible in the literature on the Central America peace movement. In the process of describing the various activities carried out by these organizations, Peace distinguishes between more leftist and moderate groups, as evidenced by the group's position on the Sandinista National Liberation Front (FSLN). More than any other organization, according to Peace, the Nicaragua Network offered the most "uncritical view" of the FSLN and accepted much of the latter's pronouncements of popularity among the Nicaraguan people."19 The Committee in Solidarity with the People of El Salvador (CISPES) also offered its unequivocal support of the Farabundo Marti National Liberation Front (FMLN) in El Salvador, but CISPES made a conscious effort to refrain from sounding too revolutionary, which is why it highlighted its educational purposes. In comparison to CISPES, the Religious Task Force on Central America did not promote the efforts of the FMLN. Nonetheless, the two groups worked well together since both emphasized the promotion of human rights and their opposition to the U.S. funding of the Contra rebels.

While Peace covers the protests and demonstrations undertaken by anti-Contra war activists, he also highlights the many educational and electoral activities of these organizations, thus illustrating the more moderate tactics used by antiwar activists. In a desire to appear respectable, the Interreligious Foundation for Community Organization (IFCO), which, beginning with Kansas in September 1983, held Central America Information Weeks in order to not appear too radical. As quoted by Peace, the director of IFCO, Lucius Walker 
explained, "We tried to keep it as simple and direct as possible and free of jargon as possible. We did not use language of the extreme left." 20 IFCO organized hundreds of events in dozens of communities across the country to educate Americans about Central America and America's role in the region.

The Coalition for a New Foreign and Military Policy's Central America Working Group (CAWG) played a leading role in uniting the distinct groups opposed to Reagan's foreign policy initiatives. Even the more radical groups, like the Nicaragua Network and CISPES, worked with CAWG in the hopes of appearing to fight for singular goals. CAWG influenced members of Congress through its relationship with the House Democratic Task Force on Central America as the two worked together under the leadership of the task force's chairman David Bonior (D-MI). Further evidence of the close work between the Central America peace movement and the U.S. Congress was the Countdown '87 Campaign to End Contra Aid. The campaign included representatives from the Coalition for a New Foreign Policy, the Nicaragua Network, Witness for Peace, and the Committee for a Sane Nuclear Policy, among others. The purpose of Countdown '87 was to pressure and lobby twenty-three members of the House of Representatives and six members of the Senate who had not yet not firmly commit to either approving or rejecting aid to the Contras. This persuasion took the form of letters, phone calls, meetings between congressmen, and editorials or advertisements in newspapers.

In early 1988 , Reagan requested $\$ 36.25$ million over four months for military and non-military use in Nicaragua. On February 3, 1988, the House rejected the measure by a vote of 219-211. Six of the congressmen who opposed the measure had been included in the list of the twenty-three congressmen that Countdown ' 87 entreated to vote no. While two of these votes came from newly elected members and another two came from congressmen who had voted against aid previously, the two other congressmen changed their vote. Yet Speaker of the House Jim Wright (D-TX) stopped the passage of Reagan's aid package by promising to put forward another bill for non-lethal aid to the Contras. This measure also failed due in part to Republicans who rejected the bill out of the belief that public opinion would soon turn in their favor regarding military aid. The Nicaragua Network and CISPES opposed the measure but, according to Robert Borosage, a board member of the Countdown '87 campaign, the better-known moderate groups used their greater influence to persuade congressmen and activists to accept the compromise.

Though some organizations played a more prominent role in the peace movement of the 1980s than others, decentralization prevented any one group from dominating the actions of the whole movement. Peace argues that the decentralized structure of the movement allowed for differences to exist without causing the movement to implode. Still, Peace concedes, the lack of leadership hurt the movement in a way because it meant that the media could not go to a 
prominent figure and find out what the movement was all about. Secondly, the lack of a common periodical, like the disarmament movement's Nuclear Times, made the range of actions undertaken by the Central America movement seem disconnected and made it difficult to create a "movement identity." 21 Lastly, Peace contends, a lack of a national centralized governing body caused disorganization since national groups and grassroots activists had little to no coordination.

A prominent theme throughout Peace's history of the anti-Contra war campaign is that the organizations involved in the peace movement strived to appear respectable in the eyes of the American public. While the reasons for such an attitude might be evident to scholars, Peace could have greatly strengthened his account of the peace movement of the 1980s if he had situated these protests within the larger history of the peace movement over time. For instance, how much of an impact did the violence associated with 1960s antiwar activists have on activists in the 1980s? Or did the attention on tactics have more to do with the conservative character of the era? Besides discussing Reagan's creation of the Office of Public Diplomacy for Latin America and the Caribbean, Peace devotes only minimal attention to the ways in which the conservative environment impacted the peace movement of the 1980s. Nonetheless, Peace's wellresearched account of the anti-Contra war campaign provides scholars looking to expand their analysis beyond Nicaragua an excellent starting point.

\section{NOTES}

1 The literature on conservatism in its various guises is, to say the least, vast. Some of the most important works include Matthew Dallek, The Right Moment: Ronald Reagan's First Victory and the Decisive Turning Point in American Politics (New York: Free Press, 2000); Donald T. Critchlow, The Conservative Ascendancy: How the GOP Right Made Political History (Cambridge: Harvard University Press, 2007); and Bruce J. Schulman and Julian E. Zelizer, eds., Rightward Bound: Making America Conservative in the 1970s (Cambridge: Harvard University Press, 2008).

${ }^{2}$ See, for instance, Mary Brennan, Wives, Mothers, and the Red Menace: Conservative Women and the Crusade against Communism (Boulder, University of Colorado Press, 2008); Donald T. Critchlow, Phyllis Schlafly and Grassroots Conservatism: A Woman's Crusade (Princeton: Princeton University Press, 2005); and Michelle Nickerson, Mothers of Conservatism: Women and the Postwar Right (Princeton: Princeton University Press, 2012). Another account that, like Self, uses the family as representative of a larger occurrence is Natasha Zaretsky, No Direction Home: The American Family and the Fear of National Decline, 1968-1980 (Chapel Hill: The 
University of North Carolina Press, 2007.

${ }^{3}$ Robert O. Self, All in the Family: The Realignment of American Democracy Since the 1960s (New York: Hill and Wang, 2012), 4-5.

4 Ibid., 100.

5 Ibid., 127-129.

${ }^{6}$ Historian Daniel Rodgers has illustrated that the shrinking of the social contract represented only part of the general movement to a small-scale individualized way of viewing everything from economics to education. The rising interest in community organization, among both the Left and the Right, according to Rodgers, represented a turn away from the expanded citizenship offered after World War II towards smaller cooperative associations. As a result, the social contract "shrank imaginatively into smaller, more partial contracts," fragmenting society further. See Daniel T. Rodgers, The Age of Fracture (Cambridge: Belknap Press, 2011), especially 198 for his analysis of the social contract.

${ }^{7}$ Self, 275.

8 Ibid., 335.

9 Ibid., 337.

10 Ibid., 297.

11 Ibid., 398.

12 Ibid., 400.

13 Ibid., 404.

14 David T. Courtwright, No Right Turn: Conservative Politics in a Liberal America (Cambridge: Harvard University Press, 2010), 4-6.

15 Self, 75.

16 As a result of historians beginning to look at the Cold War from a global perspective, a number of books offer good overviews of American interventions in the region, including Nicaragua, during the last years of the Cold War. See Odd Arne Westad, The Global Cold War: Third World Interventions and the Making of Our Times (New York: Cambridge University Press, 2007); Greg Grandin, Empire's Workshop: Latin America, the United States, and the Rise of the New Imperialism (New York: Metropolitan Books, 2006); and Hal Brands, Latin America's Cold War (Cambridge: Harvard University Press, 2010).

17 Self, 409.

18 See, for instance, Christian Smith, Resisting Reagan: The U.S. Central America Peace Movement (Chicago: University of Chicago Press, 1996); Bradford Martin, The Other Eighties: A Secret History of America in the Age of Reagan (New York: Hill and Wang, 2011); and Van Gosse and Richard Moser, eds., The World the Sixties Made: Politics and Culture in Recent America (Philadelphia: Temple University Press, 2003).

19 Roger Peace, A Call to Conscience: The Anti-Contra War Campaign (Amherst:

University of Massachusetts Press, 2012), 69.

20 Peace, 100.

21 Peace, 117. 